Egyptian Journal of Aquatic Biology \& Fisheries

Zoology Department, Faculty of Science,

Ain Shams University, Cairo, Egypt.

ISSN $1110-6131$

Vol. 23(4): 697 - 719 (2019)

www.ejabf.journals.ekb.eg

\title{
Applying Geospatial Technology in Assessing the Coastal Vulnerability of Zaranik Protectorate to Sea-Level Rise.
}

\author{
Wiame W.M. Emam ${ }^{1}$, Magdy T. Khalil ${ }^{1}$, Marian G. Nassif ${ }^{2}$, Kareem M. Soliman $^{1}$ \\ ${ }^{1}$ Zoology Department, Faculty of Science, Ain Shams University, Cairo, Egypt \\ ${ }^{2}$ National Institute of Oceanography and Fisheries, Inland Water Branch, Egypt \\ *Corresponding Author: dr_wiameemam@yahoo.com
}

\section{ARTICLE INFO}

Article History:

Received: Aug. 3, 2019

Accepted: Sept. 10, 2019

Online: Sept. 30, 2019

\section{Keywords:}

Satellite images;

DSAS;

Zaranik protectorate;

Sea-level rise (SLR);

Erosion/Accretion;

Coastal slope;

Geomorphology;

North Sinai

\section{ABSTRACT}

Considering Egypt's plan to develop eco-tourism within the Zaranik protectorate, ensuring the balance between the protectorate's environmental protection and economic development has become an urgent need to maintain the protectorate's sustainability. However, the protectorate lacks monitoring studies as well as assessing its vulnerability to sea-level rise (SLR) due to shoreline erosion. Accordingly, this study aimed at monitoring the shoreline dynamics of the protectorate over a period of 32 years (1987-2019) using geospatial technology as well as assessing its vulnerability to SLR due to shoreline erosion. The study divided the protectorate's shoreline $(32 \mathrm{~km}$ ) into three zones (eastern, middle, and western). Digital Shoreline Analysis System (DSAS) tool was integrated into ArcGIS software to facilitate analyzing the historical shoreline dynamics for both long- (1987-2019) and short-term time intervals (1987-1998, 1998-2001, 20012014, 2014-2015, 2015-2016, 2016-2017, 2017-2018, and 2018-2019) from six Landsat and three Sentinel images. Six coastal parameters were used in estimating the coastal vulnerability index (CVI). Moreover, a coastal vulnerability map was generated to identify and highlight areas most susceptible to inundation by seawater along the protectorate. Results of shoreline analysis revealed that, during 1987-2019, the protectorate's shoreline exhibited high erosion with an average rate of $-1.03 \pm 3.9 \mathrm{~m} / \mathrm{yr}$. Moreover, the tidal action, the prevailing wave directions, the oblique orientation of the shoreline, and the azimuth angle of the sandbar have all contributed in the eventual closure of Boughaz El-Zaranik since 2017. CVI results revealed that the entire coast is under the impact of very high vulnerability to SLR due to shoreline erosion. The vulnerability maps generated in the current study can be used to help in formulating the strategies required in SLR adaptation and mitigation along Zaranik protectorate's coast.

\section{INTRODUCTION}

Climate change is the most serious environmental driver affecting coastal ecosystems worldwide (Torresan $\boldsymbol{e t}$ al., 2008). Sea level rise (SLR) due to climate change has led to the loss of large areas of coastal areas (Webster et al., 2005). Mentaschi et al. (2018) found that during the period from 1984 to 2015, about 28,000 square kilometers of global coastlines were eroded due to SLR. 
Shoreline erosion due to SLR is one of the critical threats that can highly impact the coastal areas. In order to determine the suitable strategy needed to adapt to SLR, coastal scientists have used different methods to assess the coastal vulnerability. One of the most widely used methods is the coastal vulnerability index (CVI) because of its integrity and flexibility. CVI relies on a group of different geological, physical, and socioeconomic variables. In estimating CVI, Hereher (2015) used both the geological and physical aspects of the examined coast. Dinh et al. (2012) and Musa et al. (2014) focused on using the physical and human variables, whereas others used only the physical variables (Gornitz, 1991; Gornitz et al., 1994; Thieler \& Hammar-Klose, 1999; Dwarakish et al., 2009; Pendleton et al., 2010 and Yin et al., 2012).

Geomorphology, shoreline erosion/accretion rates, and coastal slope are the most common geological variables included in estimating the coastal vulnerability and using geospatial technology (Li et al., 2016 and Pantusa et al., 2018). Remote sensing (RS) technology, as a source of information, offered the availability of coherent time series of satellite image required for shoreline monitoring, in which the same area can be observed repeatedly at scales impractical to cover with traditional field techniques (Khalil et al., 2016). In coastal waters, shoreline development was successfully analyzed from Landsat images (Emam, 2016 and Fu et al., 2017). Geographic information system (GIS), as a tool, offers a suitable platform that creates, integrates, stores, visualizes, and analyzes geographically referenced data to solve problems, make decisions and manage ecosystems properly (Emam, 2016).

The European Environmental Agency (EEA) considered the Mediterranean Sea region as one of the main climate change hotspots (EEA, 2015). In Egypt, the Mediterranean coast embraces low-lying coasts (as sand dunes and lagoons). According to the Intergovernmental Panel on Climate Change (IPCC), these coasts will be significantly impacted due to SLR by 2100 (Dasgupta et al., 2007). IPCC predicted a global SLR of $0.52-0.98 \mathrm{~m}$ by 2100 due to very high greenhouse gas emissions (IPCC, 2014). Over and above, IPCC expected that African coasts will witness an increase of $10 \%$ in SLR over the global rise, by 2100 (IPCC, 2013).

Vulnerability assesses each country's ability to deal with the risks associated with climatic changes (Bridges et al., 2015). On the other hand, readiness measures the country's ability to benefit from its investments and convert them into adaptation measures. Regarding climate vulnerability, Egypt ranked $87^{\text {th }}$ and $73^{\text {rd }}$ as the most vulnerable and the least ready country, respectively (Ministry of Foreign Affairs, 2018). Thus, protecting coastal resources, especially the protected areas, from the consequences of climatic changes was one of the most important priorities identified in Egypt's Vision 2030.

Zaranik protectorate, the second oldest protected area in Egypt, is one of the most important low-lying areas lying along the Egyptian Mediterranean coast. The protectorate was established in 1983 and was designated a wetland nature reserve under the International Ramsar convention in 1988 (Khalil \& Shaltout, 2006). Despite the great importance of the protectorate, studies focusing on monitoring and analyzing the protectorate's shoreline historical dynamics as well as assessing its vulnerability to sealevel rise due to shoreline erosion are missing. Most of the studies focused on examining Bardawil Lagoon (Klein, 1986 and Nassar et al., 2018), North Sinai coast 
(Frihy \& Lotfy, 1997; El-Banna \& Hereher, 2009; and Nassar et al., 2019), and the Mediterranean coast (Hereher, 2015).

Considering Egypt's plan to develop eco-tourism within Zaranik protectorate, analyzing quantitatively the rate of shoreline change as well as assessing the protectorate's vulnerability to SLR due to shoreline erosion has become indispensable to ensure its sustainability. To this end, the current study aimed, for the first time, to assess the protectorate's vulnerability to sea-level rise due to shoreline erosion using geospatial technology. The study set the following objectives (1) analyzing quantitatively the shoreline changes for both long- (1987-2019) and short-term time intervals (1987-1998, 1998-2001, 2001-2014, 2014-2015, 2015-2016, 2016-2017, 2017-2018, and 2018-2019); (2) ranking and mapping the vulnerability of each of the geomorphology, the coastal slope, the rate of shoreline change, SLR, the mean tidal range, and the average wave height along the protectorate's shoreline; (3) assessing and mapping the overall vulnerability of the protectorate's shoreline to SLR due to shoreline erosion; and (4) identifying areas most susceptible to inundation by seawater.

\section{MATERIALS AND METHODS}

\section{Study Area}

The study area, viz. Zaranik Protectorate area (Fig. 1), the most characteristic feature along the Northern coast of Sinai, Egypt, is referenced on latitude $31^{\circ} 04^{\prime} \sim$ $31^{\circ} 12^{\prime} \mathrm{N}$ and longitude $33^{\circ} 16^{\prime} \sim 33^{\circ} 33^{\prime} \mathrm{E}$. The protectorate has a triangular shape that is located at a point $104 \mathrm{Km}$ East of Port Said and $21 \mathrm{Km}$ West of El-Arish. The shoreline of the protectorate is oriented NW-SE with an azimuth angle of N105E (Klein, 1986) and extends for about $32 \mathrm{~km}$ in length. It is bordered from the east by Bardawil lagoon, from the North by a long convex-shaped sandbar separating the lagoon from the Mediterranean Sea except for natural inlets (Fig. 1). Zaranik lagoon $\left(250 \mathrm{Km}^{2}\right)$ is a shallow natural tectonic oligotrophic hypersaline lagoon whose water is regarded as the cleanest water body amongst the Egyptian northern lakes. The protectorate hosts a wide range of rare and endemic species of fauna and flora (EIShabrawy \& Gohar, 2008). In 2001, Birdlife International has designated Zaranik protected area as an Important Bird Area (IBA) (site code EG002) (BirdLife International, 2016). All developmental activities are forbidden inside the protectorate except salt production.

The protectorate has a semiarid Mediterranean climate. El-Khamasin storms blow from the southern areas over the protectorate each year during February. The prevailing wave directions ( $\mathrm{NW}$ and $\mathrm{N}$ ) (Nassar et al., 2018) create an easterly longshore current (from west to east). 


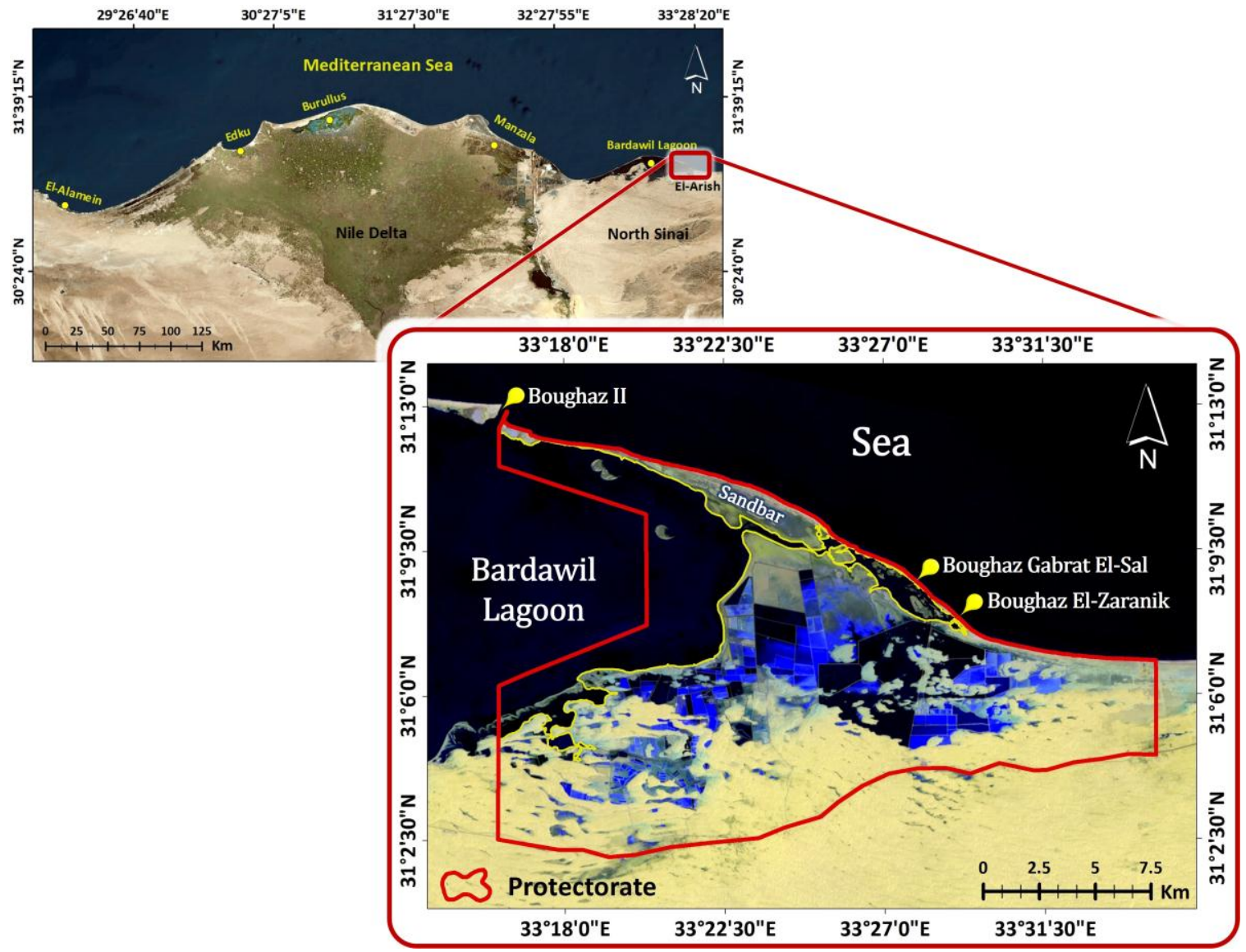

Fig. (1). Zaranik layout

\section{Dataset}

\subsection{Satellite images}

To examine the spatiotemporal shoreline dynamics along the coastline of Zaranik protectorate, a total of 9 satellite images from 1987-2019 (Table 1) (Landsat MSS (1987), Landsat TM (1998), Landsat $\mathrm{ETM}^{+}$(2001), three Landsat OLI/TIRS (2014, 2015, and 2016), and three Sentinel 2A-MSI (2017, 2018, and 2019)) were used, that is, covering a time span of 32 years. All images were chosen to be in good quality $(\mathrm{IQ}=9$ ), cloud-free (less than 10\%), and at near acquisition dates to remove the effects of seasonal differences. The images were downloaded for free from the United States Geological Survey (USGS) and corrected to the Universal Transverse Mercator (UTM) map projection system, zone 36 north on the World Geodetic Datum of 1984 (WGS 84). USGS rectified all images with a total root-mean-square error (RMSE) less than $0.44 \mathrm{~m}$. A false-color composite was used. 
Table (1): Satellite data used in the present study as obtained from United States Geological Survey

\begin{tabular}{lccc}
\hline Landsat & Path/Row & Zone & Date \\
L5_MSS & $175 / 38$ & 36 & $15-04-1987$ \\
L5_TM & $175 / 38$ & 36 & $29-04-1998$ \\
L7_ETM ${ }^{+}$ & $175 / 38$ & 36 & $29-04-2001$ \\
L8_OLI & $175 / 38$ & 36 & $25-04-2014$ \\
L8_OLI & $175 / 38$ & 36 & $28-04-2015$ \\
L8_OLI & $175 / 39$ & 36 & $30-04-2016$ \\
& & & \\
\hline Sentinel & Orbit (R) & Tile (T) & Date \\
S2A_MSI & R121 & T36RWV & $21-04-2017$ \\
S2A_MSI & R121 & T36RWV & $06-04-2018$ \\
S2A_MSI & R121 & T36RWV & $11-04-2019$ \\
\hline
\end{tabular}

L: Landsat; MSS: Multispectral Scanner; TM: Thematic Mapper; ETM ${ }^{+}$: Enhanced Thematic Mapper Plus; OLI: Operational land Imager; S2A: Sentinel 2A mission; MSI: Multispectral Instrument

\subsection{Geological and physical data}

To assess the vulnerability of the protectorate's shoreline to SLR, literature data on the geological (i.e. geomorphology and coastal slope (\%)) and the physical parameters (i.e. SLR ( $\mathrm{mm} / \mathrm{yr})$, mean tidal range $(\mathrm{m})$, and mean wave height $(\mathrm{m})$ ) (Frihy et al., 2003; Frihy et al., 2010; Hereher, 2015; and Nassar et al., 2018) of the northwestern Mediterranean coast of Egypt was used.

\section{Shoreline Extraction and Analysis}

Careful on-screen digitization for the protectorate's shoreline was applied upon the nine-satellite images using ArcGIS 10.1 software and saved separately as shapefiles. The scale of the shoreline depicted in this study ranged from 1:5,000 to $1: 20,000$.

The study utilized the freely available Digital Shoreline Analysis System (DSAS; v.4.3) toolbox extension to ESRI in ArcGIS (v.10) to analyze quantitatively the shoreline changes for both long- (1987-2019) and short-term time intervals (19871998, 1998-2001, 2001-2014, 2014-2015, 2015-2016, 2016-2017, 2017-2018, and 2018-2019).

To quantify the change in shoreline distance, DSAS calculated the net shoreline movement (NSM) through measuring the distance between the oldest and the youngest shorelines. NSM reveals the direction of the displacement. To calculate the change in rate, DSAS calculated the End-Point Rate (EPR) through dividing the distance of shoreline movement (i.e. NSM) by the time taken. In the case of accretion, a positive $(+)$ value is assigned, whereas a negative $(-)$ value indicates erosion. The study categorized the current results of erosion/accretion rates for Zaranik coast into five classes according to Natesan et al. (2015) (Table 2). 
Prior to shoreline analysis, the study created geodatabase including the digitized shoreline vectors (for the years 1987, 1998, 2001, 2014, 2015, 2016, 2017, 2018, and 2019) besides the hypothetical onshore baseline buffered $200 \mathrm{~m}$ from the shoreline position for the year 1987. DSAS cast 641 transects (T) orthogonal to the onshore baseline at $50 \mathrm{~m}$ intervals to intersect all the digitized shoreline positions. Shoreline analysis was carried out along $32 \mathrm{~km}$. The study divided the investigated shoreline into three zones; eastern (T1-T191), middle (T192-T408), and western (T409-T641) zones. Transects coincided within the tidal inlets were manually deleted. Since the number and locations of the tidal inlets were not stable along the examined time intervals, the number and ID of deleted transects varied from period to another.

\section{Assessing the Protectorate's Shoreline Vulnerability to Sea-level Rise}

Coastal vulnerability index (CVI) - developed by Gornitz et al. (1994)- is one of the most common and direct methods used to assess the coastal vulnerability to SLR due to erosion. The index integrates different variables that can influence the forces occurring along the coast. In the current study, 3 geological variables (geomorphology, coastal slope, and shoreline erosion/accretion rate) and 3 physical variables (the relative SLR, mean tide range, and the mean wave height) were used according to Thieler \& Hammar-Klose (1999).

The study used ArcGIS to create a shoreline grid composed of 89 cells covering the entire protectorate's coast $(32 \mathrm{~km})$. Each cell (measuring and mapping index unit) was sized at $500 \times 500 \mathrm{~m}$ (Fig. 2). In each cell, depending on the coastal processes exhibiting along the coast, each variable was either qualitatively or quantitatively, assigned to a certain numerical value, ranked on a linear scale from 1 to 5, corresponding to the severity of this variable according to Thieler \& Hammar-Klose (1999). The ranks of vulnerability varied from very low to very high value (Table 2 ). Except for geomorphology, all the examined variables were ranked according to their quantitative values.

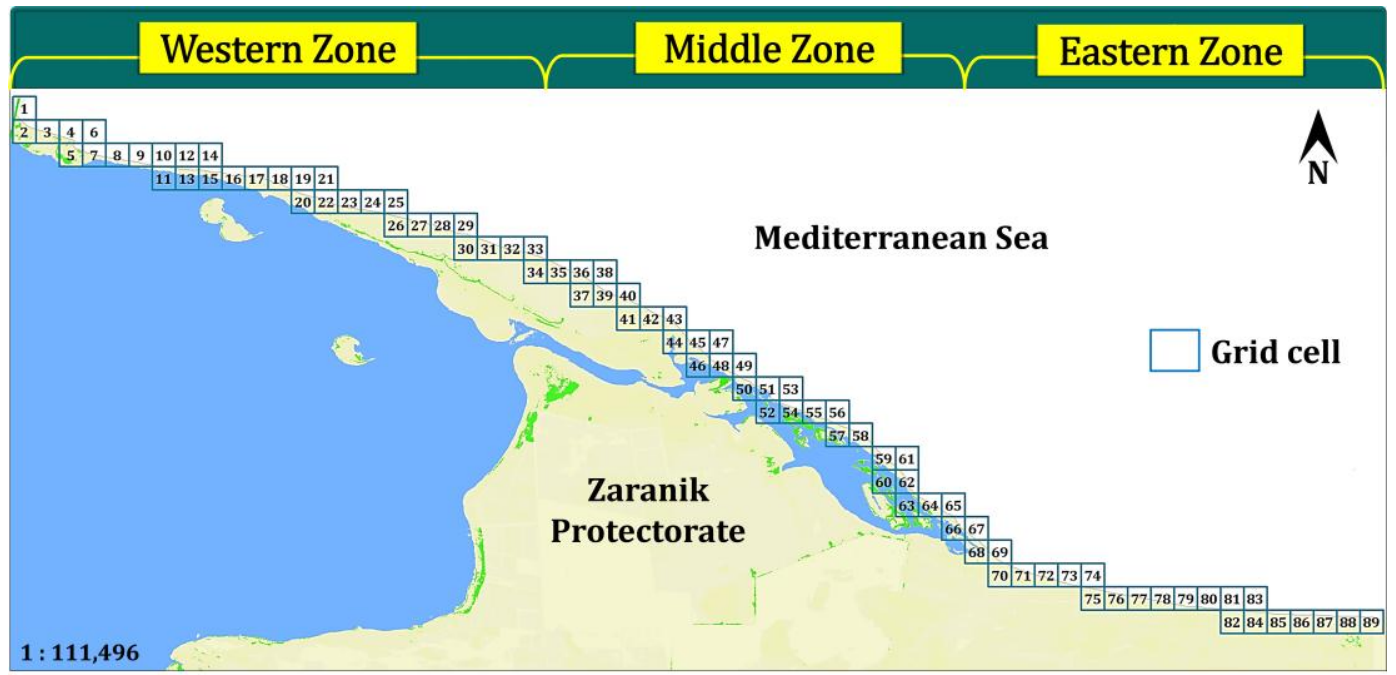

Fig. (2). Layout showing the protectorate's shoreline grid. The grid is composed of 89 cells covering the entire coast (cell size $500 \times 500 \mathrm{~m}$ ) 
For each coastal cell, CVI was calculated as the square root of the ranked variables divided by the total number of variables (Equation 1; Gornitz et al., 1994). The value of the index represents the response of the coast to the summation of these variables together.

$$
\mathrm{CVI}=\sqrt{\frac{\mathrm{a} \times \mathrm{b} \times \mathrm{c} \times \mathrm{d} \times \mathrm{e} \times \mathrm{f}}{6}} \quad \text { Equation } 1
$$

where; a) CVI rank value of geomorphology; b) CVI rank value of coastal slope (\%); c) CVI rank value of shoreline erosion/accretion rate $(\mathrm{m} / \mathrm{yr})$; d) CVI rank value of relative SLR (mm/yr); e) CVI rank value of mean tidal range (m); and f) CVI rank value of mean wave height $(\mathrm{m})$.

Based on CVI value, Gornitz et al. (1994) classified the vulnerability risk to SLR along the coast into low $(1.43 \leq \mathrm{CVI}<2.29)$, moderate $(2.29 \leq \mathrm{CVI}<3.15)$, high $(3.15$ $\leq \mathrm{CVI}<4.01)$, and very high-risk areas $(4.01 \leq \mathrm{CVI}<4.87)$. Index values less than 3 means that the coast is not vulnerable to SLR. However, index values greater than 4 reveal that the shore is at significant risk of inundation.

\section{Mapping Coastal Vulnerability to Sea-level Rise}

The six parameters selected to assess the coastal vulnerability to SLR consequences on the protectorate's coast have been ranked to be processed into the CVI equation. The ranking of each parameter as well as the overall CVI was mapped using ArcGIS to determine the hotspot areas. The study chose the red, orange, yellow, green, and blue colors to indicate very high, high, moderate, low, and very low vulnerabilities, respectively. CVI map could be used by developers, policy- and decision-makers for coastal management. 
Table (2): Rankings of the geological and physical variables used to calculate CVI \{modified after Thieler \& Hammar-Klose (1999)\}

\begin{tabular}{|c|c|c|c|c|c|}
\hline & \multicolumn{5}{|c|}{ CVI Ranks } \\
\hline & Very Low & Low & Moderate & High & Very High \\
\hline & 1 & 2 & 3 & 4 & 5 \\
\hline \multicolumn{6}{|l|}{ * Geological Variables } \\
\hline Geomorphology & $\begin{array}{l}\text { Rocky, } \\
\text { cliffed coasts }\end{array}$ & $\begin{array}{l}\text { Medium cliffs, } \\
\text { intended coasts }\end{array}$ & $\begin{array}{l}\text { Low cliffs, } \\
\text { alluvial plains }\end{array}$ & $\begin{array}{l}\text { Cobble beaches, } \\
\text { estuary, lagoon }\end{array}$ & $\begin{array}{l}\text { Barrier beaches, } \\
\text { sand beaches, } \\
\text { salt marsh, mud flats, deltas }\end{array}$ \\
\hline Coastal slope (\%) & $\begin{array}{l}\text { Steep } \\
(>12)\end{array}$ & $\begin{array}{l}\text { Medium } \\
(12-9)\end{array}$ & $\begin{array}{l}\text { Low } \\
(9-6)\end{array}$ & $\begin{array}{l}\text { Very low } \\
(6-3)\end{array}$ & $\begin{array}{l}\text { Gentle }(\cong \text { flat }) \\
(<3)\end{array}$ \\
\hline 1Rate-of-shoreline change (m/yr) & Stable & $\begin{array}{l}\text { Accretional* }^{*} \\
(0<\text { EPR } \leq 2.0)\end{array}$ & $\begin{array}{l}\text { Med. erosion } \\
(0>\text { EPR }>-0.9)\end{array}$ & $\begin{array}{l}\text { High erosion } \\
(-1.0>\text { EPR } \geq-2.0)\end{array}$ & $\begin{array}{l}\text { Severe Erosion } \\
(\mathrm{EPR}>-2.0)\end{array}$ \\
\hline \multicolumn{6}{|l|}{ * Physical Variables } \\
\hline Sea-level rise $(\mathrm{mm} / \mathrm{yr})$ & $\leq 1.8$ & $1.8 \rightarrow 2.5$ & $2.5 \rightarrow 3.0$ & $3.0 \rightarrow 3.4$ & $\geq 3.4$ \\
\hline Mean tidal range $(\mathrm{m})$ & $>6$ & $4.1 \rightarrow 6$ & $2 \rightarrow 4$ & $1 \rightarrow 1.9$ & $<1.0$ \\
\hline Mean wave height (m) & $\leq 0.55$ & $0.55 \rightarrow 0.85$ & $0.85 \rightarrow 1.05$ & $1.05 \rightarrow 1.25$ & $\geq 1.25$ \\
\hline
\end{tabular}

1) according to Natesan et al. (2015)

*) Accretion rates can be further subdivided into; medium accretion $(0<\mathrm{EPR} \leq 1)$; high accretion $(1<\mathrm{EPR} \leq 2)$; very high accretion $(\mathrm{EPR}>2)$ 


\section{RESULTS \& DISCUSSION}

\section{Shoreline Dynamics}

\subsection{Long-term Shoreline Changes}

The study calculated the net shoreline movement (NSM) to quantify and reveal the nature of shoreline displacement along Zaranik protectorate during 1987 - 2019.

NSM results showed that a total of 438 transects accounting for about $21.83 \mathrm{~km}$ of Zaranik shoreline length experienced erosion during 1987-2019 (Fig. 3) with an average landward displacement $( \pm \mathrm{SD})$ of $-96.86 \mathrm{~m}( \pm 84.09)$. Based on the length of the eroded shoreline, the western side of the protectorate was in the first rank $(11.61 \mathrm{~km})$ followed by the eastern side $(6.93 \mathrm{~km})$ then the middle of the protectorate $(3.29 \mathrm{~km})$. However, based on the maximum distance of erosion, the middle zone was higher than the eastern one. Along the western side of the protectorate, transects from T409 to T641 experienced erosion with a maximum distance of $305.06 \mathrm{~m}$ (at T566) and an average $( \pm \mathrm{SD})$ of $132.44 \mathrm{~m}( \pm 93.56)$. In the middle of the protectorate, transects from T263 to T289 $(1.35 \mathrm{~km})$ and from T291 to T329 $(1.94 \mathrm{~km})$ eroded with a maximum distance of $194.8 \mathrm{~m}$ (at T286) and an average $( \pm \mathrm{SD})$ of $95.64 \mathrm{~m}( \pm 58.62)$. Transects from $\mathrm{T} 1$ to T134 $(6.68 \mathrm{~km})$ and from T187 to T191 $(0.25 \mathrm{~km})$ along the eastern side of the protectorate experienced erosion with a maximum distance of $69.89 \mathrm{~m}$ (at T80) and an average $( \pm \mathrm{SD})$ of $37.81 \mathrm{~m}( \pm 20.16)$.

On the other hand, a total of 193 transects along the eastern and middle zones (i.e., about $9.62 \mathrm{~km}$ in length) of Zaranik shoreline experienced accretion during 1987-2019 (Fig. 3) with an average seaward displacement $( \pm \mathrm{SD})$ of $111.9 \mathrm{~m}( \pm 69.59)$. Transects from T135 to T186 $(2.59 \mathrm{~km})$, T192 to T218 $(1.35 \mathrm{~km})$, T221 to T239 $(0.95 \mathrm{~km})$, T247 to T262 $(0.80 \mathrm{~km})$, and T330 to T408 $(3.94 \mathrm{~km})$ experienced maximum shoreline displacement of $244.3 \mathrm{~m}$ (at T165), $171 \mathrm{~m}$ (at T217), $297.66 \mathrm{~m}$ (at T223), $109.87 \mathrm{~m}$ (at T247), and $184.08 \mathrm{~m}$ (at T390), respectively.

Overall, NSM changed with an average $( \pm$ SD) of $-32.98 \mathrm{~m}( \pm 125.13)$ (landward recession).

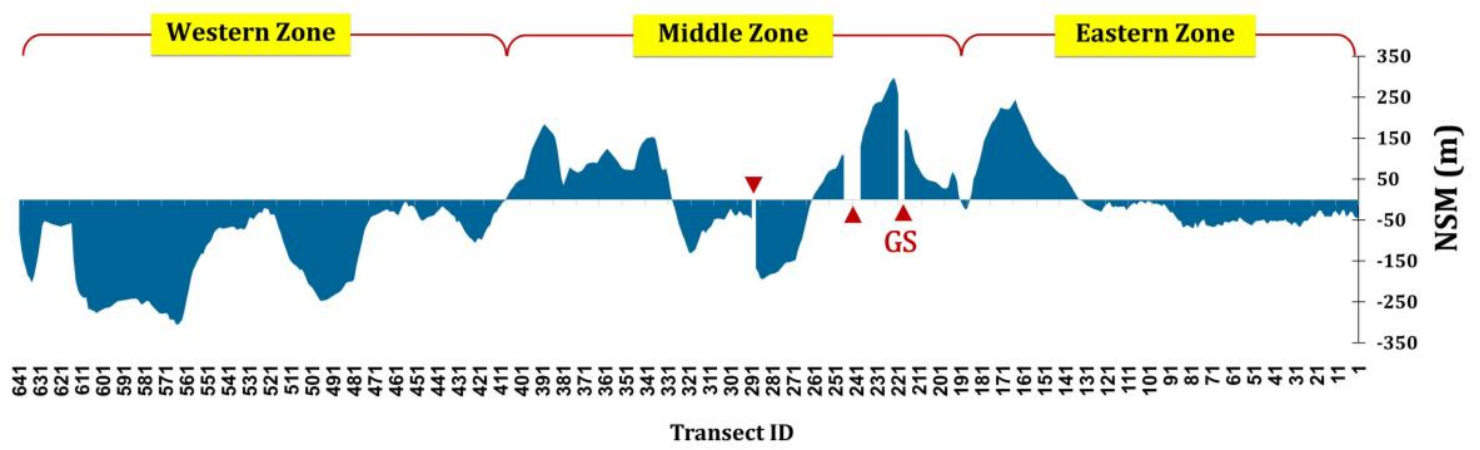

Fig. (3). NSM along the shoreline of Zaranik Protectorate during 1987-2019. Red arrows indicate the positions of the tidal inlets. GS: Boughaz Gabrat El-Sal 
The study used EPR method to calculate the rate-of-change statistics for the study period 1987-2019. EPR results revealed that 438 transects experienced erosion with an average rate $( \pm \mathrm{SD})$ of $-3.028 \pm 2.63 \mathrm{~m} / \mathrm{yr}$, whereas accretion occurred along 193 transects with an average rate $( \pm \mathrm{SD})$ of 3.50 $\pm 2.18 \mathrm{~m} / \mathrm{yr}$ during 1987-2019 (Table 3). The overall trend of the shoreline-change rate indicated high erosion, with an average rate $( \pm \mathrm{SD})$ of $-1.03 \pm 3.91 \mathrm{~m} / \mathrm{yr}$ during 1987-2019 (Table 3).

Table (3): EPR long-term shoreline changes (1987-2019) for Zaranik shoreline

\begin{tabular}{|c|c|c|c|c|c|}
\hline \multirow{3}{*}{\multicolumn{2}{|c|}{$\begin{array}{l}\text { Long-term shoreline changes } \\
\qquad(1987-2019)\end{array}$}} & \multicolumn{4}{|c|}{ EPR (m/yr) } \\
\hline & & \multicolumn{2}{|c|}{ Transect } & \multirow{2}{*}{$\begin{array}{l}\text { Min - Max } \\
(\mathrm{m} / \mathrm{yr})\end{array}$} & \multirow{2}{*}{ Av. \pm SD } \\
\hline & & No. & $\%$ & & \\
\hline \multirow{4}{*}{ Accretion (m/yr) } & Very high & 141 & 22.35 & $2.01-9.31$ & $4.35 \pm 1.92$ \\
\hline & High & 34 & 5.39 & $1.01-1.99$ & $1.52 \pm 0.28$ \\
\hline & Medium & 18 & 2.85 & $0.08-0.96$ & $0.59 \pm 0.30$ \\
\hline & & & & & $3.5 \pm 2.18$ \\
\hline \multirow[t]{2}{*}{ No Change } & & 0 & 0 & 0 & 0 \\
\hline & Medium & 97 & 15.37 & $(-0.98)-(-0.04)$ & $-0.58 \pm 0.27$ \\
\hline \multirow[t]{3}{*}{ Erosion (m/yr) } & High & 141 & 22.35 & $(-2)-(-1.01)$ & $-1.53 \pm 0.29$ \\
\hline & Very high & 200 & 31.70 & $(-9.54)-(-2.01)$ & $-5.27 \pm 2.34$ \\
\hline & & & & & $-3.03 \pm 2.63$ \\
\hline \multicolumn{2}{|l|}{ Total } & 631 & 100 & $-9.54-9.31$ & $-1.03 \pm 3.91$ \\
\hline \multicolumn{2}{|l|}{ Overall trend } & \multicolumn{4}{|c|}{ High Erosion } \\
\hline
\end{tabular}

\subsection{Short-term Shoreline Changes}

The amount of change in shoreline position determined by NSM for Zaranik Protectorate throughout eight short-term time intervals (1987-1998, 1998-2001, 20012014, 2014-2015, 2015-2016, 2016-2017, 2017-2018, and 2018-2019) is summarized in Table (4) and displayed in Fig. (4).

Throughout the period from 2014 to 2019 , more than $91 \%$ of the total transects exhibited shoreline displacement in the range of 0.01 to $50 \mathrm{~m}$ (Fig. 4) with average NSM values of $6.108,7.49,7.47,17.19$, and $9.06 \mathrm{~m}$ during 2014-2015, 2015-2016, 2016-2017, 2017-2018, and 2018-2019, respectively (Table 4).

A recurring pattern in the shoreline dynamics in terms of erosion and accretion was observed during successive intervals (Table 4; Fig. 4). For instance, during 19871998 , about $66.6 \%$ of the shoreline length exhibited erosion. After that during 1998$2001,49.2 \%$ of Zaranik shoreline exhibited accretion. Also, throughout the period from 2001-2015, more than 60\% of the shoreline length exhibited erosion. Afterward, throughout the period from 2015-2017, about $68 \%$ of the shoreline length exhibited accretion. Also, during 2017-2018, about $91.8 \%$ of the shoreline length exhibited erosion. However, after one year, during 2018-2019, 71.9\% of Zaranik shoreline exhibited accretion.

The recurring pattern of erosion and accretion was also observed at Boughaz Gabrat El-Sal (GS) during the last 5 years (2014-2019) (Fig. 4) where T216 recorded the highest eroded distance during 2014-2015, and then recorded the highest accreted 
distance in the next year (2015-2016) (Table 4). In the same manner, this observation was repeated for T239 during 2017-2018 and 2018-2019. However, during 2016-2017, the inlet was closed (Fig. 4).

Seawater flows into Zaranik lagoon via temporary natural tidal inlets at the middle and eastern zones of the protectorate. Fig. (4) revealed that both the number and locations of these tidal inlets varied from time to time. In consistence with Embabi \& Moawad (2014), the present study recorded three natural tidal inlets. The study observed these three inlets during 1987-1998, 2001-2014, 2014-2015, 2015-2016, and 2017-2018 (Fig. 4). During 1998-2001 and 2016-2017, only two natural openings were observed, whereas, during 2018-2019, the study recorded five small openings (Fig. 4). An old map from the Egyptian Survey Authority for the year 1935 revealed the presence of four natural openings (Embabi \& Moawad, 2014).

On leaving the lagoon, the seawater concentrates in certain pathways. By time, these pathways deepen forming canals of various sizes that later connect to form the tidal inlets (Embabi \& Moawad, 2014). Emam (2016) attributed the discrepancy in the number and locations of tidal inlets to the tide and surging waves affecting the sandbar. During high tide, waves split the bar at weak points forming natural inlets, whereas low tide, gradually silt up the inlet and close it. In addition, the prevailing wave directions (NW and N) (Nassar et al., 2018), the NW-SE shoreline oblique orientation, and the N105E azimuth angle of Zaranik sandbar boosted the eastward longshore current (Klein, 1986) resulting in the ultimate closure of Boughaz El-Zaranik since 2017 (Fig. 5).

Table (5) analyzed the rate of shoreline change (EPR) along Zaranik Protectorate coast in eight periods. The overall trend of EPR in Zaranik Protectorate coast indicated that, during the intervals 2015-2016, 2016-2017, and 2018-2019, the coast suffered very high accretion with average EPR values of 7.43, 7.68, and 8.94 $\mathrm{m} / \mathrm{yr}$, respectively. On the other hand, the greatest amount of erosion occurred during 2017-2018 (-17.9 m/yr) and 2014-2015 (-6.05 m/yr). During 1987-1998 and 20012014 , the coast exhibited high erosion with average EPR values of -1.09 and -1.47 $\mathrm{m} / \mathrm{yr}$, respectively. During 1998-2001, the coast exhibited moderate erosion with an average EPR value of $-0.39 \mathrm{~m} / \mathrm{yr}$.

El-Banna \& Hereher (2009) indicated that, throughout the period from 1986 to 2001, the net change (erosion/accretion) in the landmass on both sides of Boughaz II was about $-1,686 \mathrm{~m}^{2}(\cong 0.02 \%)$. The rate of erosion was $69,968 \mathrm{~m}^{2} /$ year. Whereas, the rate of accretion was $69,855 \mathrm{~m}^{2} /$ year. 
Fig. (4). NSM along Zaranik coast during eight intervals. Red arrows indicate the positions of the tidal inlets (Z: Boughaz ElZaranik; GS: Boughaz Gabrat El-Sal)

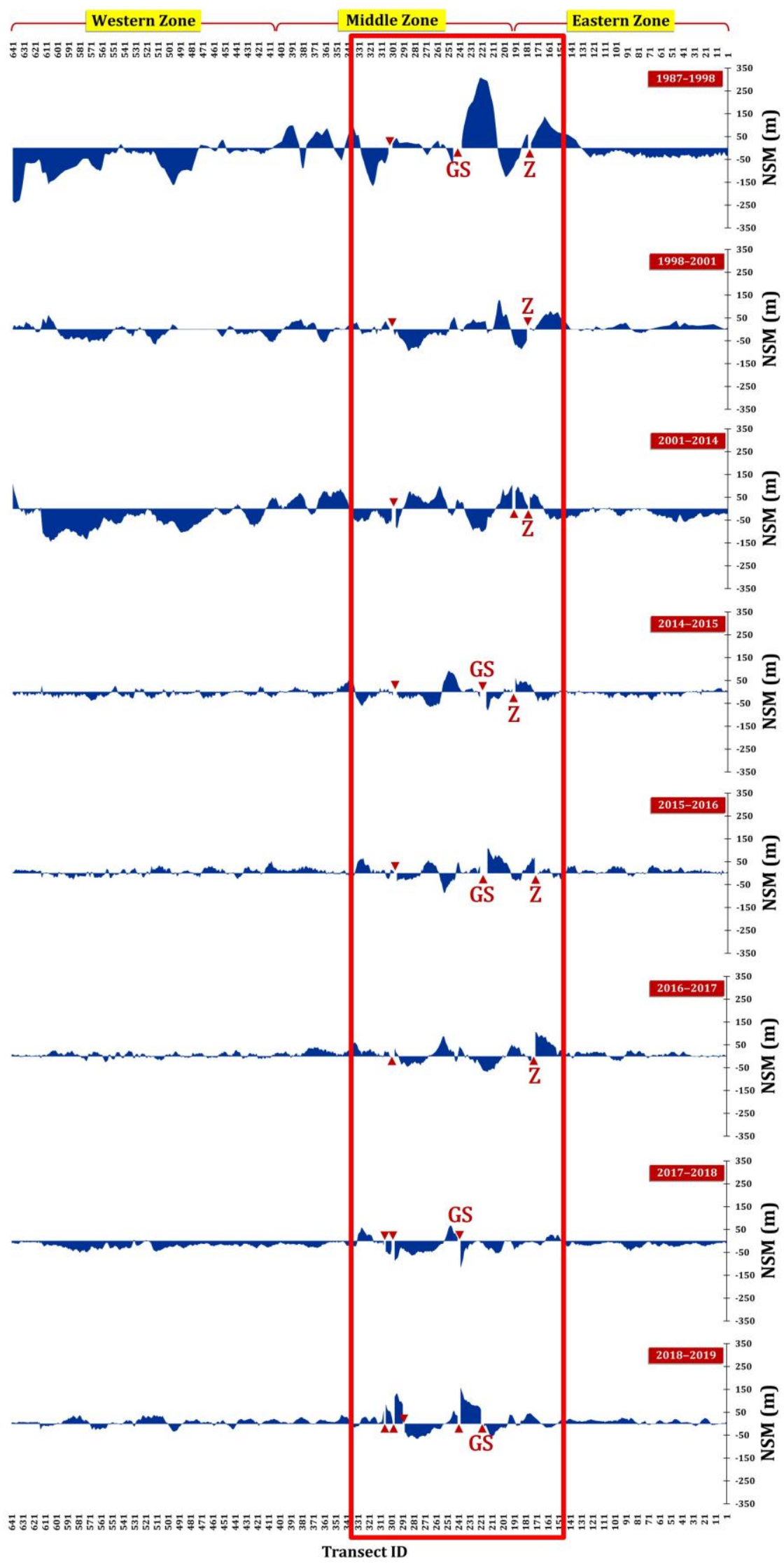


Table (4): Amount of shoreline position change determined by NSM method for Zaranik Protectorate

\begin{tabular}{|c|c|c|c|c|c|c|c|c|c|c|c|c|c|}
\hline \multirow{3}{*}{ Interval } & \multicolumn{13}{|c|}{ NSM (m) } \\
\hline & \multirow{2}{*}{ HED (T\#) } & \multirow{2}{*}{ HAD (T\#) } & \multirow{2}{*}{ Av. \pm SD } & \multicolumn{3}{|c|}{ Shoreline length (km); percentage (\%) } & \multicolumn{6}{|c|}{ Number of transects } & \multirow{2}{*}{$\operatorname{Total}^{(\mathrm{a})}$} \\
\hline & & & & Accretion & Stable & Erosion & $\mathbf{0}$ & $0.01 \leq \mathbf{5 0}$ & $\mathbf{5 0} \leq \mathbf{1 0 0}$ & $100 \leq 200$ & $200 \leq 300$ & $>\mathbf{3 0 0}$ & \\
\hline 1987-1998 & $-238.8\left(\mathrm{~T}_{639}\right)$ & $307.9\left(\mathrm{~T}_{222}\right)$ & $-12.04 \pm 80.62$ & $10.4(33.3 \%)$ & - & $20.8(66.6 \%)$ & - & 375 & 157 & 71 & 22 & 4 & 629 \\
\hline 1998-2001 & $-93.97\left(\mathrm{~T}_{287}\right)$ & $128.1\left(\mathrm{~T}_{206}\right)$ & $-1.121 \pm 31.57$ & $15.6(49.2 \%)$ & $2.14(6.76 \%)$ & $13.9(44.0 \%)$ & 43 & 520 & 69 & 4 & - & - & 636 \\
\hline 2001-2014 & $-143.6\left(\mathrm{~T}_{607}\right)$ & $107.2\left(\mathrm{~T}_{641}\right)$ & $-19.12 \pm 31.50$ & $9.32(29.4 \%)$ & $0.20(0.63 \%)$ & $22.1(69.9 \%)$ & 4 & 402 & 192 & 37 & - & - & 635 \\
\hline 2014-2015 & $-80.48\left(\mathrm{~T}_{216}\right)$ & $91.53\left(\mathrm{~T}_{251}\right)$ & $-6.108 \pm 21.20$ & $8.92(28.4 \%)$ & $0.05(0.16 \%)$ & 22.5 (71.5\%) & 1 & 599 & 31 & - & - & - & 631 \\
\hline $2015-2016$ & $-86.15\left(\mathrm{~T}_{255}\right)$ & $108.04\left(\mathrm{~T}_{216}\right)$ & $7.492 \pm 21.71$ & $21.4(68.3 \%)$ & - & 9.94 (31.7\%) & - & 600 & 29 & 2 & - & - & 631 \\
\hline $2016-2017$ & $-68.02\left(\mathrm{~T}_{215}\right)$ & $106.05\left(\mathrm{~T}_{172}\right)$ & $7.471 \pm 22.40$ & $21.7(68.6 \%)$ & $0.05(0.16 \%)$ & 9.85 (31.2\%) & 1 & 596 & 36 & 2 & - & - & 635 \\
\hline 2017-2018 & $-114.7\left(\mathrm{~T}_{239}\right)$ & $67.44\left(\mathrm{~T}_{248}\right)$ & $-17.19 \pm 19.22$ & $2.58(8.18 \%)$ & - & $29.02(91.8 \%)$ & - & 607 & 28 & 1 & - & - & 636 \\
\hline 2018-2019 & $-65.53\left(\mathrm{~T}_{278}\right)$ & $155.7\left(\mathrm{~T}_{239}\right)$ & $9.069 \pm 27.49$ & $22.8(71.9 \%)$ & $0.05(0.16 \%)$ & $8.84(27.9 \%)$ & 1 & 579 & 44 & 10 & - & - & 634 \\
\hline
\end{tabular}

NSM: Net Shoreline Movement (m); HED: highest eroded distance; HAD: highest accreted distance; T\#: transect number; Av \pm SD: Average \pm Standard Deviation.

(a): Indicate the total number of transects remained — after deleting those coincided within the tidal inlets - during each interval. 


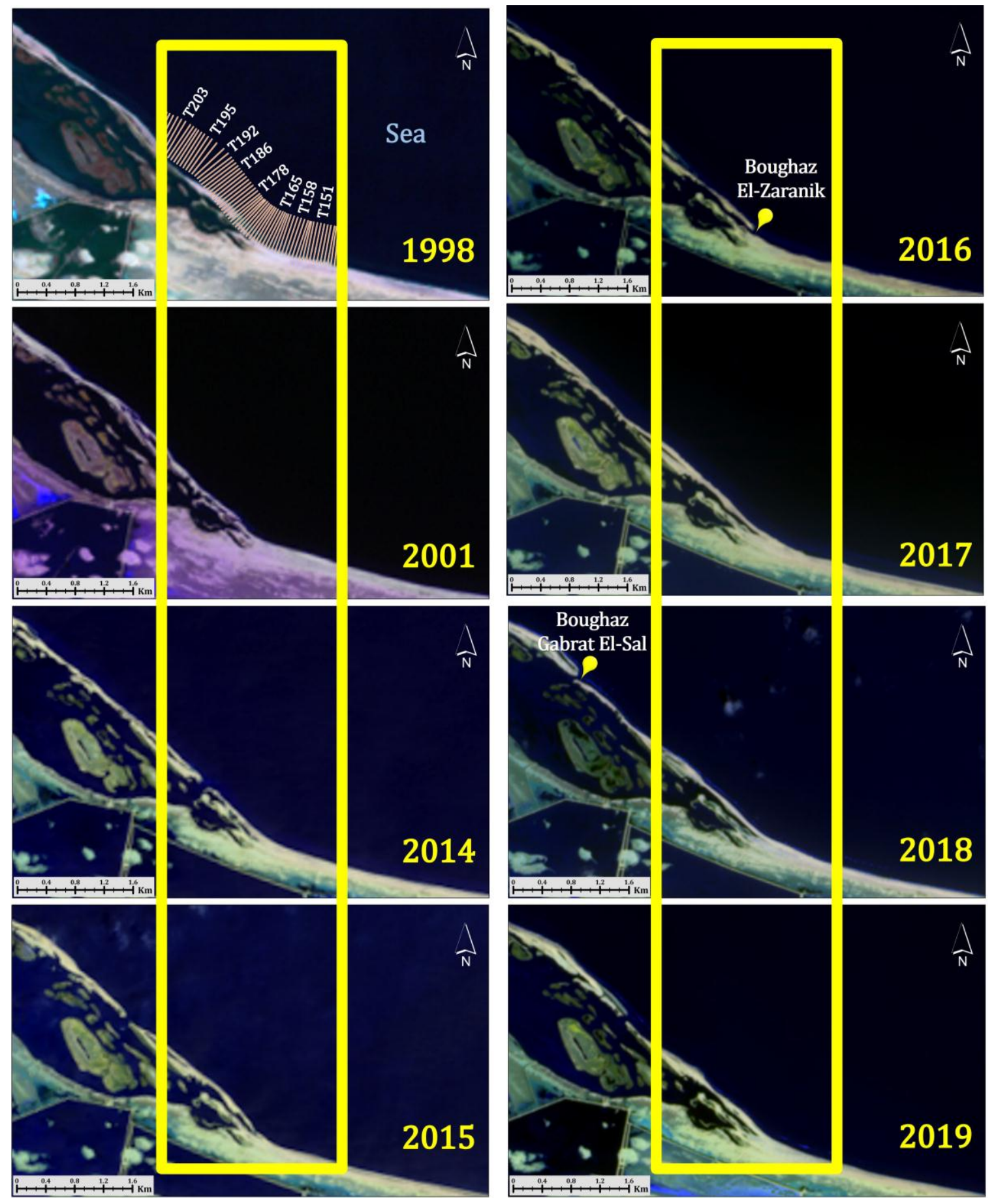

Fig. (5). Landsat (1998, 2001, 2014, 2015, and 2016) and Sentinel (2017, 2018, and 2018) data showing the changes occurring along the transects from T151 to T192 at Boughaz El-Zaranik $($ Scale $=1: 22,420)$ 
Table (5): Analysis of EPR short-term changes along Zaranik Protectorate coast

\begin{tabular}{|c|c|c|c|c|c|c|c|c|}
\hline \multirow{2}{*}{ Interval } & \multicolumn{3}{|c|}{ Accretion (m/yr) } & \multicolumn{3}{|c|}{ Erosion (m/yr) } & \multirow{2}{*}{$\begin{array}{c}\text { Av. } \\
(\mathrm{m} / \mathrm{yr})\end{array}$} & \multirow{2}{*}{$\begin{array}{l}\text { Overall EPR } \\
\text { trend }\end{array}$} \\
\hline & Min. & Max. & Av. \pm SD & Min. & Max. & $\mathrm{Av} . \pm \mathrm{SD}$ & & \\
\hline 1987-1998 & 0.02 & 27.9 & $6.232 \pm 6.65$ & -0.01 & -21.6 & $-4.76 \pm 4.18$ & -1.09 & $\mathrm{HE}$ \\
\hline 1998-2001 & 0.07 & 42.7 & $7.476 \pm 6.79$ & -0.05 & -31.3 & $-9.18 \pm 7.33$ & -0.37 & ME \\
\hline 2001-2014 & 0.01 & 8.26 & $3.11 \pm 2.11$ & -0.01 & -11.1 & $-3.41 \pm 2.53$ & -1.47 & $\mathrm{HE}$ \\
\hline $2014-2015$ & 0.11 & 90.8 & $16.96 \pm 19.95$ & -0.01 & -79.8 & $-15.2 \pm 12.9$ & -6.05 & VHE \\
\hline $2015-2016$ & 0.05 & 107.2 & $17.31 \pm 16.87$ & -0.04 & -85.5 & $-13.8 \pm 13.6$ & 7.43 & VHA \\
\hline 2016-2017 & 0.14 & 109.0 & $17.72 \pm 18.23$ & -0.01 & -69.9 & $-14.4 \pm 16.1$ & 7.68 & VHA \\
\hline $2017-2018$ & 0.14 & 70.33 & $23.66 \pm 19.1$ & -0.08 & -119.7 & $-21.6 \pm 15.4$ & -17.9 & VHE \\
\hline $2018-2019$ & 0.07 & 153.6 & $19.25 \pm 23.1$ & -0.01 & -64.65 & $-17.5 \pm 16.9$ & 8.94 & VHA \\
\hline
\end{tabular}

MA: Medium Accretion; HA: High Accretion; VHA: Very High Accretion; ME: Medium Erosion; HE: High Erosion.

\section{Ranking the vulnerability of each variable along the protectotate's shoreline}

\subsection{Coastal geomorphology}

Geomorphology displays the relative susceptibility of different landform types to erosion (Thieler \& Hammar-Klose, 1999). In the present study, the western and the middle zones of the protectorate's coast $(22.5 \mathrm{~km})$ are occupied by Zaranik Lagoon which is connected to the Mediterranean Sea through natural tidal inlets. A concave coastal sandy barrier separates the lagoon from the sea. On the other hand, the eastern zone of the protectorate's coast $(9.49 \mathrm{~km})$ is covered by quaternary aeolian sand deposits and coastal crescentic (barchan) sand dunes up to $2 \mathrm{~m}$ (Hereher, 2015). Although sand dunes can act as a temporal barrier to any variations of the sea level, any prolonged SLR will loosen sand grains leading to severe erosion (Hereher, 2015).

Thus, the numerical values corresponding to the coastal geomorphology of the protectorate's coast were " 4.0 " for western and middle zones (lagoon) and " 5.0 " for the eastern zone (sandy coast) (Table 6; Fig. 6a).

\subsection{Coastal slope (\%)}

Coastal slope refers to the percent of land steepness. It is a crucial factor, if not the most important, in determining the CVI, because any small rise in the sea level can surpass the gentle sloping coasts faster than the steep sloping coasts (Hereher, 2015). The elevation map generated by Hereher (2015) for the Egyptian Mediterranean coast during 2000 revealed that the entire coast of the protectorate has a gentle slope coast (i.e. $<3 \%$ ). Accordingly, the coast was assigned a CVI value of "5.0" and is highly vulnerable for inundation by seawater (Table 6; Fig. 6b). 


\subsection{Shoreline erosion/accretion rates $(\mathrm{m} / \mathrm{yr})$}

Results of shoreline analysis revealed that, during 1987-2019, about 11.61, 3.29 , and $6.93 \mathrm{~km}$ of the shoreline in the western, middle, and eastern zones, respectively exhibited erosion (Fig. 3). Shoreline erosion causes shoreline retreat of the lagoon's barrier and hence reduces its function as a nature protective line from sea invasion (Fanos et al., 1995 and Emam, 2016). Accordingly, grid cells exhibiting very high erosion (EPR >-2 m/yr), high erosion ( $-1>E P R \geq-2 \mathrm{~m} / \mathrm{yr})$, and medium erosion $(0>\mathrm{EPR} \geq-0.9 \mathrm{~m} / \mathrm{yr})$ were given CVI values of " 5.0 ; red colour", "4.0; orange colour", and "3.0; yellow colour", respectively (Fig. 6c). On the other hand, about $9.62 \mathrm{~km}$ of the shoreline experienced accretion. Accretional cells $(0<\mathrm{EPR} \leq 2 \mathrm{~m} / \mathrm{yr})$ were given a CVI value of "2.0; green colour" (Table 6; Fig. 6c).

Table (6): Vulnerability value associated to each variable \& the estimated CVI values for each zone

\begin{tabular}{lccc}
\hline \multirow{2}{*}{ Variable } & \multicolumn{3}{c}{ Vulnerability value } \\
\cline { 2 - 4 } & Western & Middle & Eastern \\
\hline Length $(\mathrm{km})$ & 11.6 & 10.901 & 9.499 \\
Geomorphology & 4 & 4 & 5 \\
Coastal slope & 5 & 5 & 5 \\
Coastal erosion & 5 & 2 & 2 \\
Sea-level rise & 3 & 3 & 3 \\
Tidal range & 5 & 5 & 5 \\
Wave height & 1 & 1 & 1 \\
Mean CVI & 15.81 & 10 & 11.18 \\
\hline
\end{tabular}

\subsection{Sea-level rise $(\mathrm{mm} / \mathrm{yr})$}

Frihy et al. (2010) reported a value of $2.8 \mathrm{~mm} / \mathrm{yr}$ for the SLR along the coast east of Port Said (i.e. North Sinai coast). Thus, the current study assigned a value of 3.0 for this parameter in the CVI equation (Table 6; Fig. 6d).

Sea levels are expected to continue rising for centuries, even if greenhouse gas emissions are curbed and their atmospheric concentrations stabilized. Shaltout \& Omstedt (2014) reported that, during 1993-2010, the Mediterranean Sea-level increased significantly by $2.6 \mathrm{~mm} / \mathrm{yr}$ along the northern coast of Africa. IPCC predicted that by 2080-2100, if the temperature along the African coasts increased by 2 or $4^{\circ} \mathrm{C}$, the sea level would rise by about 60-80 or $85-125 \mathrm{~cm}$, respectively (IPCC, 2013).

\subsection{Average tidal range $(\mathrm{m})$}

Zaranik coast is characterized by semidiurnal microtidal pattern. Nassar et al. (2018) recorded tidal range value of $55 \mathrm{~cm}$ during 2010 at the western side of Boughaz I of Bardawil Lagoon. Accordingly, a value of 5.0 was assigned for this parameter in the CVI equation (Table 6; Fig. 6e). 


\subsection{Average wave height $(\mathrm{m})$}

In the investigated region, wave action has a seasonal pattern in terms of direction and intensity. Low north-west waves prevail during spring and summer, whereas relatively higher north and north-west waves occur in winter. Throughout the year, the average wave height of the Mediterranean coast of Egypt as reported by Frihy et al. (2003) is $0.5 \mathrm{~m}$. Thus, a value of 1.0 was applied in the CVI equation throughout the entire coast (Table 6, Fig. 6f).

\section{Assessing the protectorate's vulnerability to sea-level rise}

The estimated CVI values for Zaranik coast varied between 10 and 15.81 (Table 6). Based on the severity for each zone, CVI average values followed the order of western (15.81)> eastern (11.18) > middle zone (10) (Table 6). CVI results along the entire coast were very high (CVI>5) describing the entire coast as being under the impact of very high vulnerability to the SLR. Hereher (2015) reported the same result on the shoreline extending from the Nile Delta to El-Arish in North Sinai $(420 \mathrm{~km})$.

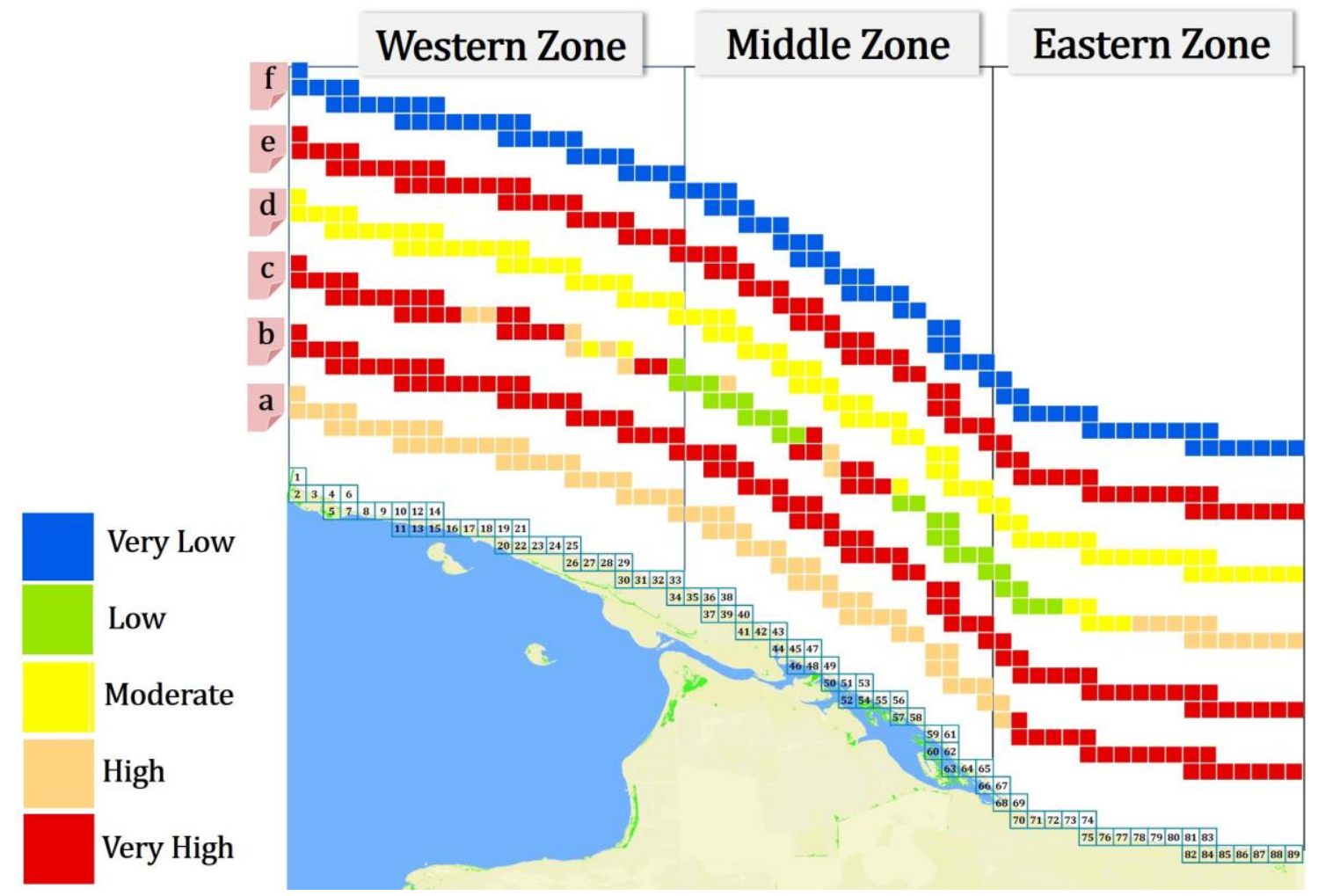

Fig. (6). Cartographic map showing the vulnerability of each parameter along the coast.

a) geomorphology; b) coastal slope; c) shoreline erosion/accretion rate; d) SLR;

e) mean tidal range; f) mean wave height 
Emam (2016) found that throughout the period from 1984 to 2014, Zaranik Lagoon lost about $10.9 \%$ of its surface area $\left(0.03 \mathrm{Km}^{2} /\right.$ year $)$. In the present study, the very high vulnerability of the Zaranik coast to the SLR is mainly due to its being a lowlying coast with a gentle slope and to the high rate of erosion the shoreline experienced throughout the last 3 decades.

Since the entire coast of Zaranik was very highly affected by sea-level rise, the colors in the CVI map were used to reveal actual CVI cell values, rather than using the ranking categories (Fig. 7). It was clear that about 49 and $24.7 \%$ of protectorate's coastline (44 and 22 cells) exhibited CVI values of 15.81 and 10, respectively. Whereas, $25 \%$ of the coastline (23 cells) varied from 11.18 to 14.14.

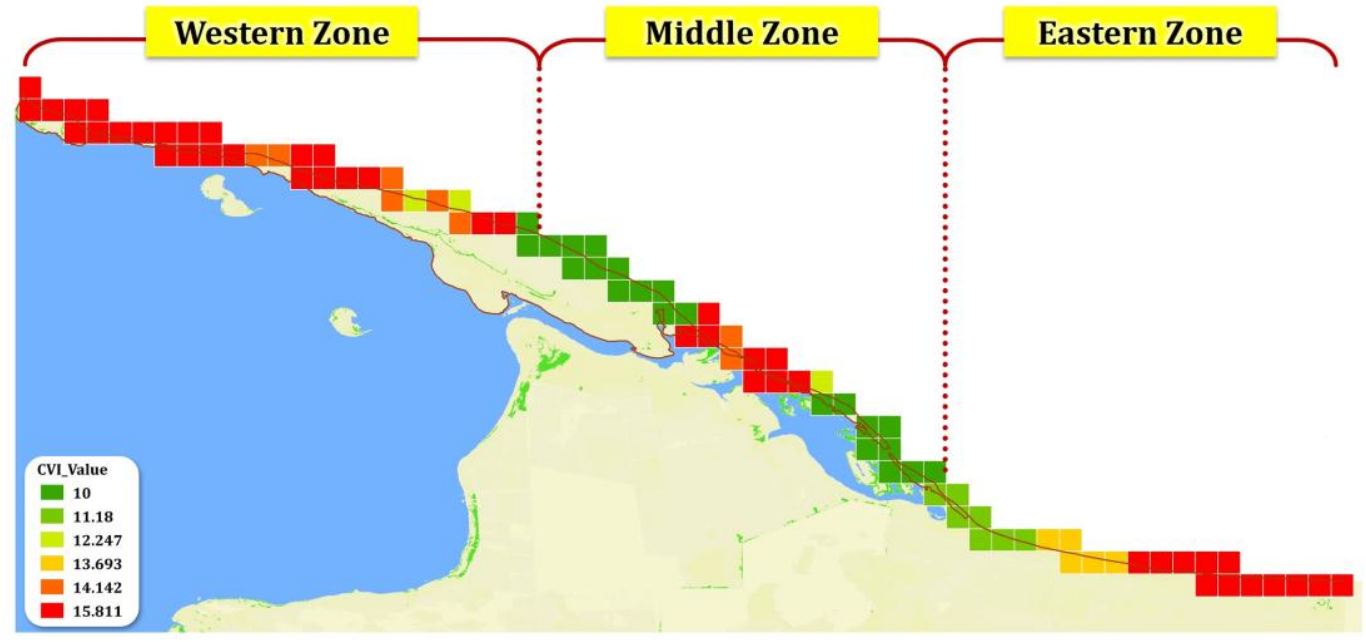

Fig. (7). Coastal vulnerability index map showing the relative vulnerability of the coastline of Zaranik protectorate to changes due to SLR. The map displays the cells where the effects of SLR may be the greatest

Conventional solutions to protect coastal areas from erosion due to SLR include seawalls, jetties, dikes (Pranzini, 2018), and beach nourishment actions (Hinkel et al., 2013). Depending on the local conditions, such strategies focusing on using hard infrastructure might be effective, but they often have unforeseen side-effects, such as transferring erosion to downdrift shorelines (Mentaschi et al., 2018). Recently, rather than converting our coastlines into artificially built environments, a broad variety of Nature-Based/Green Solutions (as using plants and natural elements in constructing living shorelines) have been proposed to preserve and ensure the sustainable use of coastal habitats (Temmerman et al., 2013 and Nesshöver et al., 2017). The feasibility of implementing a green project depends on the characteristics of each site (Ruckelshaus et al., 2016). Another important consideration is that a higher degree of nature requires more time and space. In critical situations, where time and space are limited, a less natural alternative may provide a temporary solution that needs to change over time. Accordingly, urgent environmental studies are needed to identify the best green solutions that can be applied, determine their requirements, and evaluate their future impacts along the protectorate's coast. 


\section{CONCLUSION}

In conclusion, results of the current study revealed that, throughout the period from 1987-2019, the protectorate's shoreline exhibited high erosion with an average rate of $-1.03 \pm 3.9 \mathrm{~m} / \mathrm{yr}$. The length of Zaranik shoreline exhibited a recurring pattern of erosion and accretion at successive intervals. Also, Boughaz Gabrat El-Sal exhibited a recurring pattern of erosion and accretion during the last 5 years (2014-2019). Over and above, the tidal action, the prevailing wave directions, the oblique orientation of the shoreline, and the azimuth angle of the sandbar have all contributed in the eventual closure of Boughaz El-Zaranik since 2017.

Integrating the geological and physical variables into the vulnerability index facilitated producing an overview of their interactions along the protectorate's coast. CVI results showed that the entire coast of Zaranik protectorate is under the impact of very high vulnerability to SLR due to shoreline erosion.

Finally, the study recommended:

1. Developing sustainable response strategies to find out the most suitable adaptation measures. Increasing public awareness and green solutions can be used in the adaptive strategy.

2. Using the coastal vulnerability index map generated in the current study to help in formulating the strategies required in SLR adaptation and mitigation along the protectorate's coast. Also, the spatial mapping for the six variables used in the present study can greatly support in choosing the most suitable adaptation strategies.

\section{REFERENCES}

Birdlife International (2016). Important Bird Area and Biodiversity factsheet: Lake Bardawil. http://www.birdlife.org/datazone/sitefactsheet.php?id=6187

Bridges, T.S.; Wagner, P.W.; Burks-Copes, K.A.; Bates, M.E.; Collier, Z.A.; Fischenich, C.J.; Gailani, J.Z.; Leuck, L.D.; Piercy, C.D.; Rosati, J.D.; Russo, E.J.; Shafer, D.J.; Suedel, B.C.; Vuxton, E.A. and Wamsley, T. (2015). Use of Natural and Nature-Based Features (NNBF) for Coastal Resilience. ERDC SR-151.Vicksburg, MS: US Army Engineer Research and Development Center.

Dasgupta, S.; Laplante, B.; Murray, S. and Wheeler, D. (2007). Sea-level rise and storm surges: A comparative analysis of impacts in developing countries. Washington (DC): World Bank Group. Policy Research Working Paper WPS4901. $43 \mathrm{pp}$.

Dinh, Q.; Balica, S.; Popescu, I. and Jonoski, A. (2012). Climate change impact on flood hazard, vulnerability and risk of the Long Xuyen Quadrangle in the Mekong Delta. International Journal of River Basin Management, 10(1): 103-120. https://doi.org/10.1080/15715124.2012.663383

Dwarakish, G.S.; Vinay, S.A.; Natesan, U.; Asano, T.; Kakinuma, T.; Venkataramana, K.; Pai, B.J. and Babita, M.K. (2009). Coastal vulnerability 
assessment of the future sea level rise in Udupi coastal zone of Karnataka state, west coast of India. Ocean and Coastal Management, 52(9): 467-478. https://doi.org/10.1016/j.ocecoaman.2009.07.007

EEA (European Environmental Agency) (2015). Mediterranean Sea Region Briefing. The European Environment. https://www.eea.europa.eu/soer2015/countries/ mediterranean

El-Banna, M.M. and Hereher, M.E. (2009). Detecting temporal shoreline changes and erosion/accretion rates, using remote sensing, and their associated sediment characteristics along the coast of North Sinai, Egypt. Environmental Geology, 58 (7): 1419-1427. https://doi.org/10.1007/s00254-008-1644-y

El-Shabrawy, G.M. and Gohar, M.E. (2008). Physical, chemical, and biotic influences on zooplankton composition in Zaranik Lagoon, Egypt. Thalassia Salentina, 31: 163-182.

Emam, W.W.M. (2016). Management plan for enhancing Bardawil Lagoon productivity using Remote Sensing and Geographic Information System. Ph.D. Thesis, Zoology Department, Faculty of Science, Ain Shams University, 335 pp.

Embabi, N.S. and Moawad, M.B. (2014). A semi-automated approach for mapping geomorphology of El Bardawil Lake, Northern Sinai, Egypt, using integrated remote sensing and GIS techniques. The Egyptian Journal of Remote Sensing and Space Sciences, 17(1): 41-60. https://doi.org/10.1016/j.ejrs.2014.02.002

Fanos, A. M.; Naffaa, M. G.; Fouad, E.E. and Omar, W. (1995). Seasonally and yearly wave regime and climate of the Mediterranean coast of Egypt. COPEDEC IV, Rio de Janeiro, Brazil.

Frihy, O.E. and Lotfy, M.F. (1997). Shoreline changes and beach-sand sorting along the northern Sinai coast of Egypt. Geo-Marine Letters, 17:140-146. https://doi.org/10.1007/s003670050019

Frihy, O.E.; Deabes, E.A. and Elsayed, W.R (2003). Processes reshaping the Nile Delta promontories of Egypt: pre- and post-protection. Geomorphology, 53(3-4): 263-279. https://doi.org/10.1016/S0169-555X(02)00318-5

Frihy, O.E.; Deabes, E.A. and Gindy, A.A.E. (2010). Wave Climate and Nearshore Processes on the Mediterranean Coast of Egypt. Journal of Coastal Research, 26(1): 103-112. http://www.jstor.org/stable/27752790

Fu, Y.; Guo, Q.; Wu, X.; Fang, H. and Pan, Y. (2017). Analysis and prediction of changes in coastline morphology in the Bohai Sea, China, using remote sensing. Sustainability, 9(6): 900. https://doi.org/10.3390/su9060900

Gornitz, V.M. (1991). Global coastal hazards from future sea level rise. Global and Planetary Change, 3(4): 379-398. https://doi.org/10.1016/0921-8181(91)90118-G

Gornitz, V.M.; Daniels, R.C.; White, T.W. and Birdwell, K.R. (1994). The Development of a Coastal Risk Assessment Database: Vulnerability to Sea-Level Rise in the U.S. Southeast. Journal of Coastal Research. p 327-338. http://www.jstor.org/stable/25735608 
Hereher, M.E. (2015). Coastal vulnerability assessment for Egypt's Mediterranean coast. Geomatics, Natural Hazards and Risk Journal, 6(4): 342-355. https://doi.org/10.1080/19475705.2013.845115

Hinkel, J.; Nicholls, R.J.; Tol, R.S.J.; Wang, Z.B.; Hamilton, J.M.; Boot, G.; Vafeidis, A.T.; McFadden, L.; Ganopolski, A. and Klein, R.J.T. (2013). A global analysis of erosion of sandy beaches and sea-level rise: an application of DIVA. Global and Planetary Change, 111: 150-158. https://doi.org/10.1016/j. gloplacha.2013.09.002

IPCC (International Panel on Climate Change) (2013). Summary for policymakers. In: Stocker TF, Qin D, Plattner G-K, Tignor M, editors. Climate change 2013: The physical science basis. Contribution of Working Group I to the Fifth Assessment Report of the Intergovernmental Panel on Climate Change. Cambridge (UK): Cambridge Univ. p 1-30. https://doi.org/10.1017/cbo9781107415324.summary

IPCC (International Panel on Climate Change) (2014). Climate change 2014: Impacts, adaptation, and vulnerability. Part A: Global and sectoral aspects. In: Field CB, Barros VR, Dokken DJ, editors. Contribution of Working Group II to the Fifth Assessment Report of the Intergovernmental Panel on Climate Change. Cambridge (UK): Cambridge Univ. 1150 pp.

Khalil, M.T. and Shaltout, K.H. (2006). Lake Bardawil; Zaranik Protected Area. Publication of National Biodiversity Unit, No. 15, Egyptian Environmental Affairs Agency, Egypt, 580 pp.

Khalil, M.T.; Saad, A.A.; Ahmed, M.H.M.; El Kafrawy; S.B. and Emam W.W.M. (2016). Integrated Field Study, Remote Sensing and GIS Approach for Assessing and Monitoring Some Chemical Water Quality Parameters in Bardawil Lagoon, Egypt. International Journal of Innovative Research in Science, Engineering and Technology, 5(8): 14657-14669.

Klein, M. (1986). Morphological changes of the artificial inlets of the Bardawil lagoon. Estuarine, Coastal and Shelf Science, 22(4):487-493. https://doi.org/10.1016/0272$\underline{7714(86) 90070-3}$

Li, Y.; Zhang, X.; Zhao, X.; Ma, S.; Cao, H. and Cao, J. (2016). Assessing spatial vulnerability from rapid urbanization to inform coastal urban regional planning. Ocean and Coastal Management, 123: 53-65. https://doi.org/10.1016/j. ocecoaman.2016.01.010

Mentaschi, L.; Vousdoukas, M.I.; Pekel, J.-F.; Voukouvalas, E. and Feyen, L. (2018). Global long-term observations of coastal erosion and accretion. Scientific Reports, 8:12876. https://doi.org/10.1038/s41598-018-30904-w

Ministry of Foreign Affairs (2018). Climate Change Profile | Egypt. Published by: Ministry of Foreign Affairs of the Netherlands. 17pp. https://www.government.nl/ documents/publications/2019/02/05/climate-change-profiles

Musa, Z.N.; Popescu, I. and Mynett, A. (2014). The Niger Delta's vulnerability to river floods due to sea level rise. Natural Hazards and Earth System Sciences, 14(12): 3317-3329. https://doi.org/10.5194/nhess-14-3317-2014 
Nassar, K.; Mahmod, W.E.; Fath, H.; Masria, A.; Nadaoka, K. and Negm, A. (2019). Shoreline change detection using DSAS technique: Case of North Sinai coast, Egypt. Marine Georesources \& Geotechnology, 37(1): 81-95. https://doi.org/10.1080/1064119X.2018.1448912

Nassar, K.; Mahmod, W.E.; Masria, A.; Fath, H. and Nadaoka, K. (2018). Numerical simulation of shoreline responses in the vicinity of the western artificial inlet of the Bardawil Lagoon, Sinai Peninsula, Egypt. Applied Ocean Research, 74: 87-101. https://doi.org/10.1016/j.apor.2018.02.015

Natesan, U.; Parthasarathy, A.; Vishnunath, R.; Kumar, G.E.J. and Ferrer, V.A. (2015). Monitoring long-term shoreline changes along Tamil Nadu, India using geospatial techniques. Aquatic Procedia, 4:325-332. https://doi.org/10.1016/j.aqpro. 2015.02.044

Nesshöver, C.; Assmuth, T.; Irvine, K.N.; Rusch, G.M.; Waylen, K.A.; Delbaere, B.; Haase, D. et al. (2017). The science, policy and practice of nature-based solutions: an interdisciplinary perspective. Science of the Total Environment, 579: 1215-1227. https://doi.org/10.1016/j.scitotenv.2016.11.106

Pantusa, D.; D’Alessandro, F.; Riefolo, L.; Principato, F. and Tomasicchio, G.R. (2018). Application of a coastal vulnerability index. A case study along the Apulian Coastline. Italy. Water, 10(9): 1218. https://doi.org/10.3390/w10091218

Pendleton, E.A.; Barras, J.A.; Williams, S.J. and Twitchell, D.C. (2010). Coastal vulnerability assessment of the Northern Gulf of Mexico to sea-level rise and coastal change. US Geological Survey. Open-File Report 2010-1146. https://doi.org/10.3133/ofr20101146

Pranzini, E. (2018). Coastal erosion and shore protection: a brief historical analysis. Journal of Coastal Conservation, 22: 827-830. https://doi.org/10.1007/s11852-017$\underline{0521-9}$

Ruckelshaus, M.H.; Guannel, G.; Arkema, K.; Verutes, G.; Griffin, R.; Guerry, A.; Silver, J.; Faries, J.; Brenner, J. and Rosenthal, A. (2016). Evaluating the benefits of green infrastructure for coastal areas: location, location, location. Coastal Management, 44 (5): 504-516. https://doi.org/10.1080/08920753. 2016. 1208882

Shaltout, M. and Omstedt, A. (2014). Recent dynamic topography changes in the Mediterranean Sea analyzed from altimetry data. Current Development in Oceanography, 7(1-2): 1-26. http://www.pphmj.com/abstract/8789.htm

Temmerman, S.; Meire, P.; Bouma, T.J.; Herman, P.M.J.; Ysebaert, T. and De Vriend, H.J. (2013). Ecosystem-based coastal defence in the face of global change. Nature, 504:79-83. https://doi.org/10.1038/nature12859

Thieler, E.R. and Hammar-Klose, E.S. (1999). National assessment of coastal vulnerability to sea-level rise, US Atlantic coast (Open-File Report no. 99-593, 1 sheet). Woods Hole (MA): United States Geological Survey. https://pubs.usgs. gov/of/1999/of99-593/ 
Torresan, S.; Critto, A.; Dalla Valle, M.; Harvey, N. and Marcomini, A. (2008). Assessing coastal vulnerability to climate change: comparing segmentation at global and regional scales. Sustainability Science, 3: 45-65. https://doi.org/10.1007/s11625-008-0045-1

Webster, P.J.; Holland, G.J.; Curry, J.A. and Chang, H.R. (2005). Changes in tropical cyclone number, duration, and intensity in a warming environment. Science, 309 (5742):1844pp. . https://doi.org/10.1126/science.1116448

Yin, J.; Yin, Z.; Wang, J. and Xu, S. (2012). National assessment of coastal vulnerability to sea-level rise for the Chinese coast. Journal of Coastal Conservation, 16(1): 123-133. https://doi.org/10.1007/s11852-012-0180-9 